\title{
Recent advances in sperm maturation in the human epididymis
}

\author{
Trevor G. Cooper \\ Institute of Reproductive Medicine of the University, Münster, Germany
}

\begin{abstract}
As spermatozoa move through the human epididymis they encounter a varied environment with respect to the proteins with which they come into contact. In the proximal epididymis sperm are subjected to the action of enzymes and exposure to proteins involved in membrane modification. In the middle region another set of proteins and enzymes predominates; those associated with sterol transport could modify the sperm membrane to permit the uptake of GPI-anchored zona binding proteins P34H and CD52. More distally sperm encounter increasing activities of lytic enzymes, proteins involved in both zona binding and oocyte fusion, the major maturation antigen CD52, antimicrobial activity and decapacitation factors, that help them to survive before ejaculation. Adherence of the proteins to different domains (e.g. anterior acrosome or equatorial acrosomal segment) may depend on the nature of the protein, the lipid composition of the particular membrane and the ionic environment in the epididymal lumen. The eventual location on a capacitated sperm (acrosomal membrane) or acrosome-reacted sperm (equatorial region) may dictate their role in, for example, zona-binding (P34H) or oocyte-binding (gp20). Both proteins and membranes may be modified during epididymal transit by the enzymes which may add to or remove carbohydrates and peptides from the sperm surface.
\end{abstract}

Key words : sperm maturation, human epididymis, epididymal proteins.

\section{INTRODUCTION}

The current success of testicular sperm extraction for overcoming childlessness may give the impression that the epididymis is not necessary for the fertilisation process but the falsity of this argument has been expounded (see [7]). Scarcity of intact human epididymides and the futility of taking biopsies from its single convoluted duct [45] has certainly delayed research on this organ in comparison with the human testis. Nevertheless, tissue has been used from autopsies and accident victims and at operations for prostatic carcinoma, radical prostatectomy and transplantation. The complexity of the human epididymal caput [50] and the uncertainly of which regions have been sampled in many studies leave the field less clear than it could be. Nevertheless, the accumulated data (presented here graphically and in tabular form) reveal a pattern of maturation not unlike that found in other animals that have been studied more systematically. This review updates the information relating to the changes that occur to spermatozoa during maturation in the human epididymis.

Less is known, even in animals, about the mechanism by which the epididymis influences the maturing spermatozoa. The application of molecular biology techniques to the human epididymis over the last 10 years has complemented the earlier work on specific proteins $[14,15]$. This literature has been reviewed here from which it is evident that spermatozoa are subjected to an ever changing environment in the epididymis and come sequentially into

\footnotetext{
Correspondance

Trevor G. Cooper, Institute of Reproductive Medicine of the University, Münster, Domagkstraße 11, D-48129 Münster, Germany

Tel: +49-251-8352045; Fax: +49-251-8356093; e-mail: cooper@uni-muenster.de

Communication au XVII/ Congrès de la Société

d'Andrologie de Langue Française, Montpellier, 13-15

décembre 2001.
} 
contact with proteins that have the potential to modify sperm-egg interactions.

\section{SPERM MATURATION IN THE HUMAN EPIDIDYMIS}

\section{Morphology}

Subjecting human epididymal sperm to the same procedures as ejaculated sperm for morphology results in artefactual swelling of many sperm in the caput region [47, 52] but not in the cauda. This maturational changes in the ability to resist air drying before fixation and staining was an unexpected demonstration of a maturation change that seems to affect primate spermatozoa [22]. The percentage of 'normal' sperm heads thus increases upon maturation (Fig. 1a), not as a result of removal of abnormal cells but by the appearance of a more resistant cell type. The dimensions of the heads of the non swollen sperm also changes upon maturation, and they become smaller (Fig. 1b).

Cell shrinkage may reflect dehydration caused by high intraluminal osmotic pressure, but little is known about this in man. Haidl et al [25] have suggested that abnormal sperm morphology is related to human epididymal dysfunction.

\section{Motility}

Sperm obtained from epididymal spermatocoeles (representing testicular fluid trapped within blind-ending efferent ducts [9]) are motile, as are those obtained in the caput epididymidis. The percentage of motile sperm (assessed subjectively upon release into suitable medium) increases as they pass through the epididymis but in the old men examined a decrease in motility was observed in the cauda (Fig. 1c). This is thought to reflect the ageing population of sperm stored there that had not been voided in the aged patients. Computer aided sperm motion analysis reveals an improvement in the velocity and linearity of the sperm tracks (Fig. 1c). The velocity of the sperm from the corpus are as fast as those of ejaculated (caudal) sperm from younger men, attesting to the normal functioning of the maturation process in these patients.

Initiation of motility may be a time-dependent phenomenon, rather than a result of epididymal secretions, since sperm recovered from the testis and caput are only motile after ductal occlusion $[30,38]$ and sperm obtained by testicular biopsy become motile upon incubation [13].

\section{Sperm zona binding}

The first results on the binding of human epididymal to human zona pellucida did not detect differences in binding capacity $[10,20]$ (Fig. 1d). This was most likely due to the non-physiological conditions employed (low temperature to reduce the velocity of the more mature cells in order to remove bias towards them by a greater number of spermegg collisions) since use of accepted capacitation condi- tions reveals a marked difference between caput sperm, that are unable to bind to the zona, and ejaculated (cauda) spermatozoa that can (Fig. 1d).

Epididymal proteins have been implicated in the binding of sperm to the zona pellucida (see Table 1).

\section{Acrosome reaction}

The zona pellucida stimulates the spermatozoon to undergo the acrosome reaction (a fusion of the plasma membrane and the outer acrosomal membrane and eventual loss of these vesicles formed). In the absence of large numbers of human zonae, a calcium ionophore has been used to challenge sperm to undergo the acrosome reaction. The percentage of spontaneously acrosome reacted human epididymal sperm is high but similar in all epididymal regions (Fig. 1e). Upon challenge with ionophore, however, the response of cauda cells is greater than that of corpus cells and caput sperm do not respond at all (Fig. 1e). Clearly a change in the response of the cells to calcium influx occurs upon maturation that results in their being able to acrosome react.

Epididymal sterol binding and lipid binding proteins (see Table 1) are capable of making membranes more fluid, which is a prerequisite for acrosomal vesiculation. Human epididymal dysfunction has been associated with abnormally high sperm membrane rigidity [54].

\section{Acrosin content}

The proteolytic enzyme acrosin within the acrosome is liberated and the bound enzyme exposed on the inner acrosome membrane after the acrosome reaction. The amount of acro$\sin$ in the head has been measured from the area of a gelatin film that is digested by the enzyme released from sperm dried on the film (Fig. 1f). A smaller area of digestion is found around more mature sperm heads [26], but this may indicate a shift from soluble to bound acrosin rather than a loss of enzyme or reduction in activity.

\section{Sperm vitellus binding and fusion}

Capacitated and acrosome-reacted spermatozoa are able to bind to and eventually fuse with the vitelline membrane after their passage through the zona. Using the ethically acceptable, species-insensitive zona-free hamster oocyte as surrogate, capacitated human epididymal spermatozoa display an increasing ability to penetrate eggs (Fig. 1g). These results may partly be explained by the increased incidence of acrosome reacted sperm in the mature population, but still a difference between the response of corpus and cauda sperm, which can acrosome react, is evident.

As noted above (see 4) epididymal secretions may be involved in modulating plasma membrane fluidity.

\section{Chromatin condensation}

The condensation of chromatin that occurs during epididymal maturation has been monitored indirectly by the exclu- 

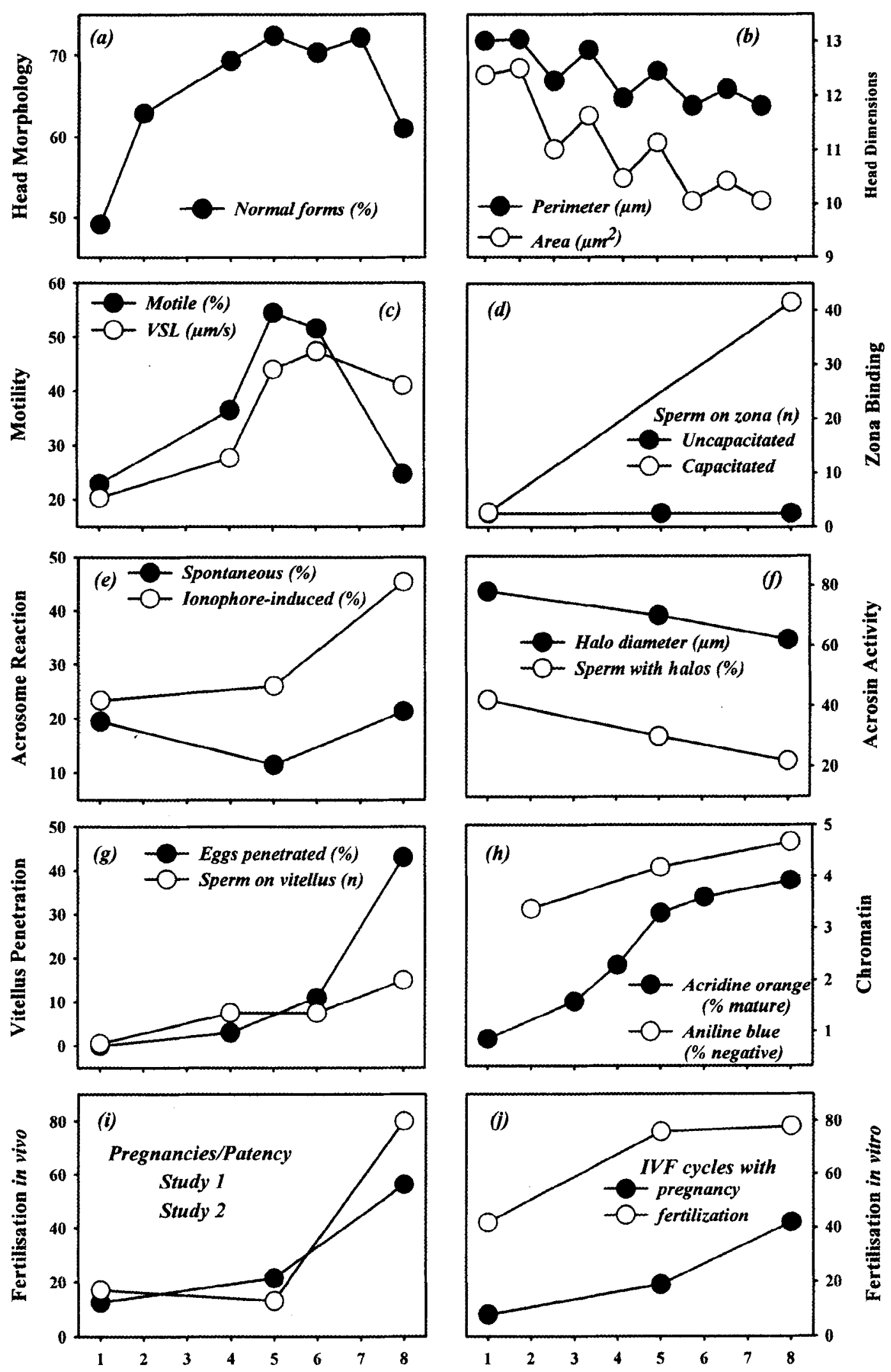

\section{Region of the Epididymis}

Figure 1: Maturation of sperm in the human epididymis. Various functional parameters (ordinate) are plotted for sperm obtained from different epididymal regions (abscissa): (a) normal forms [47]; (b) sperm head morphometry [47]; (c) motility and kinematics [51]; (d) spermzona binding [10, 39]; (e) acrosome reactions [52]; $(f)$ acrosin content [26]; (g) sperm-egg fusion [40]; (h) chromation condensation [23, 26]; (i) fertilisation after epididymovasostomy [19, 46]; (j) fertilisation in vitro [41]. 
Table 1 : Human testicular and epididymal proteins suggested to be involved in human sperm-zona binding/penetration and motility. Name (Pseudonyms, orthologues, activity)

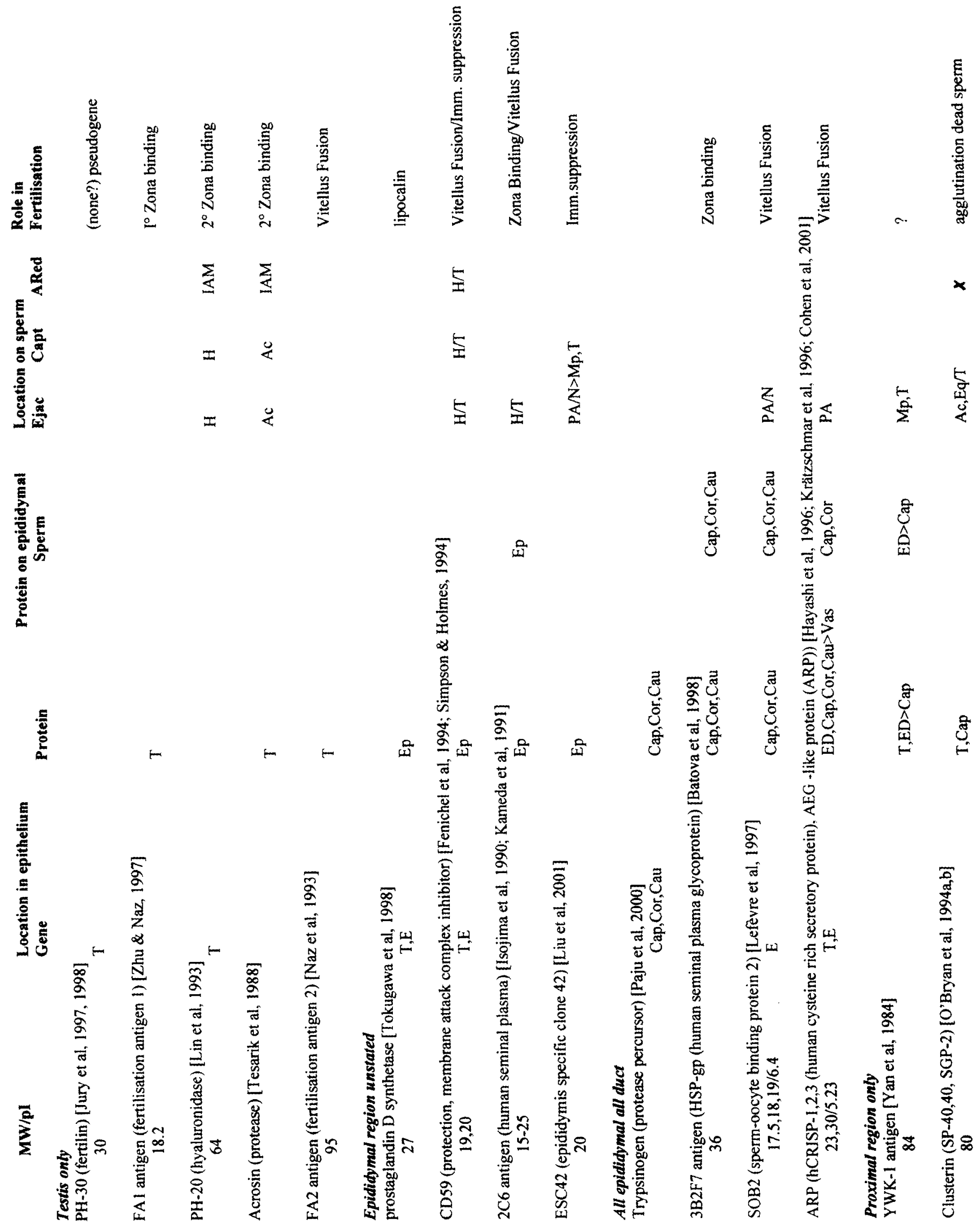



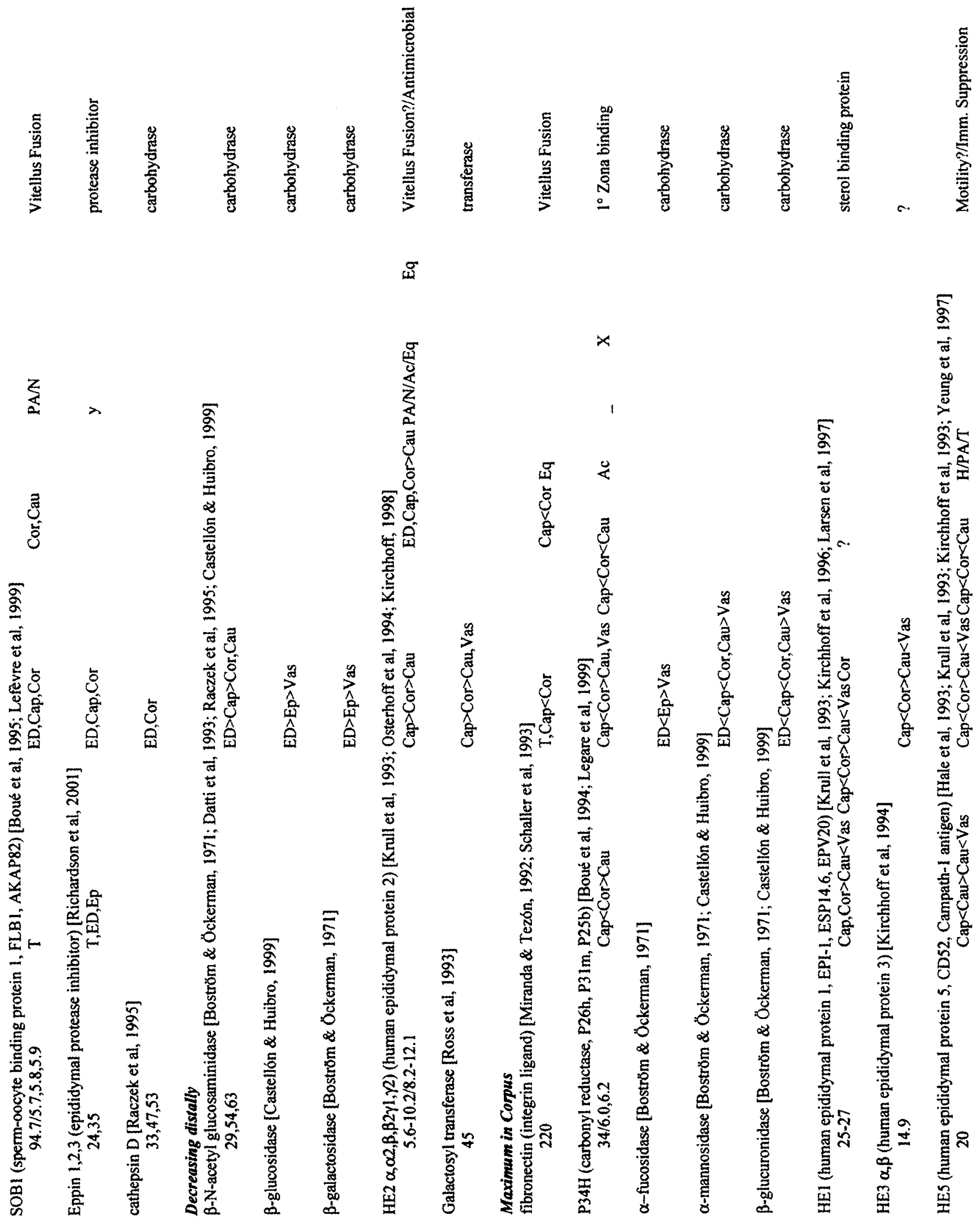
Table 1: Human testicular and epididymal proteins suggested to be involved in human sperm-zona binding/penetration and motility.

Name (Pseudonyms, orthologues, activity)

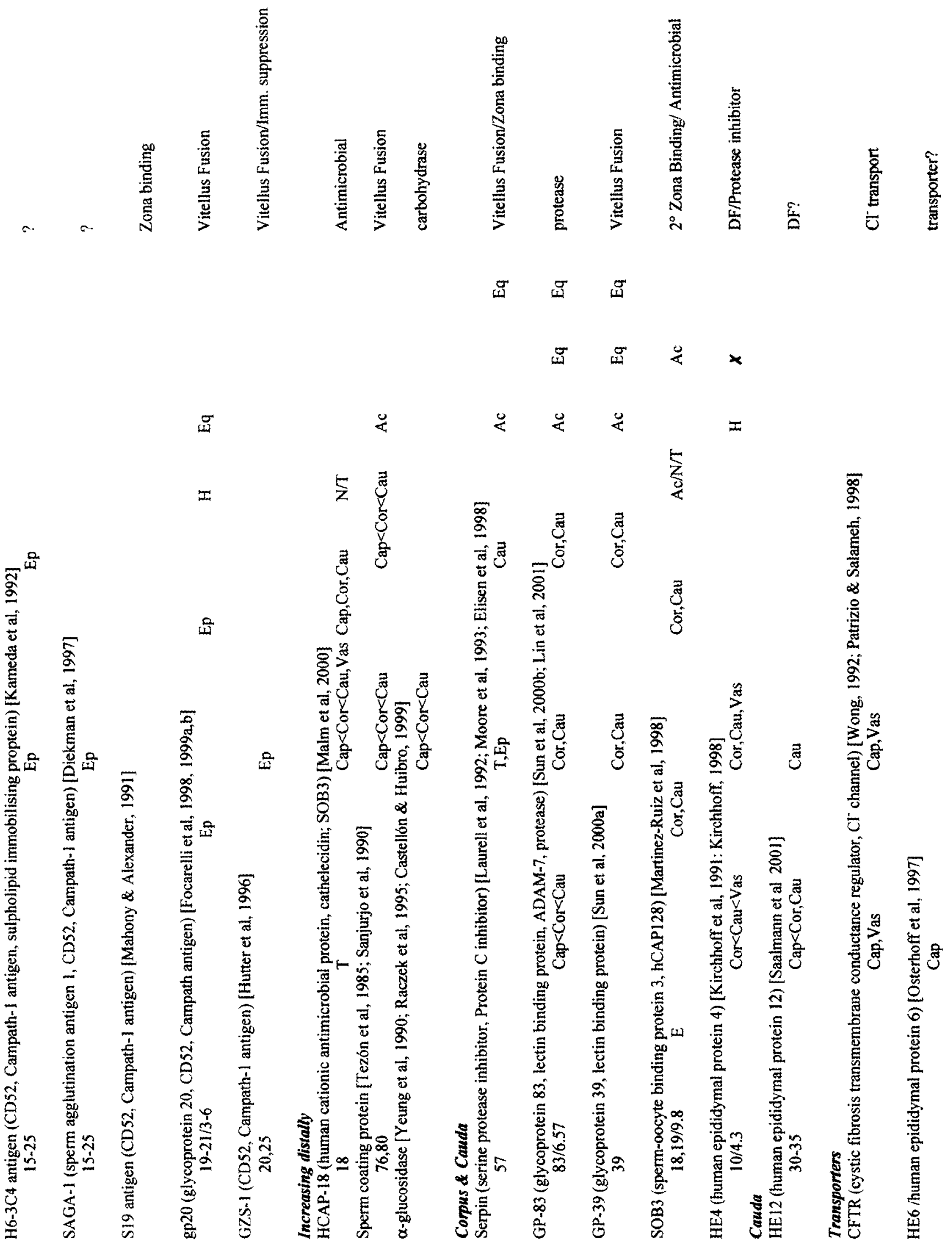


$\Uparrow$ increased; 8 , not present; ?, unknown; $1^{\circ}$, primary; $2^{\circ}$, secondary; Ac, acrosome; ARed, acrosome reacted sperm; Capt, capacitated sperm; Cap, caput; Cau, cauda; Cor, corpus; E, epididymis; Ed, efferent ducts; Ejac, ejaculated sperm; Ep, epididymal region not stated; Eq, equatorial; H, whole head; IAM, inner acrosomal membrane; Mp, midpiece; N, neck; PA, post-acrosomal; T, tail; T, testis; Vas, vas deferens; $y$, present, region not given.

\section{References table 1}

Batova, I, N., Ivanova, M. D., Mollova, M. V. \& Kyurkchiev, S. D. (1998) Human sperm surface glycoprotein involved in human sperm-zona pellucida interaction. Int J Androl, 21, 141-153.

Bostrom, K. \& Ockerman, P. A. (1971) Glycosidases in human semen and male genital organs. Scand J Urol Nephrol, 5, 117-122.

Boué, F., Berube, B., De Lamirande, E., Gagnon, C. \& Sullivan, R. (1994) Human sperm-zona pellucida interaction in inhibited by an antiserum against a hamster sperm protein. Biol Reprod, 51, 577-587.

Boué, F., Duquenne, C., Lassalle, B., Lefèvre, A. \& Finaz, C. (1995) FLB1, a human protein of epididymal origin that is involved in the sperm-oocyte recognition process. Biol Reprod, 52, 267-278.

Castellón, E. A. \& Huidobro, C. C. (1999) Androgen regulation of glycosidase secretion in epithelial cell cultures from human epididymis. Human Reprod. 14, 1522-1527.

Cohen, D. J., Ellerman, D. A., Busso, D., Morgenfeld, M. M., Piazza, A. D., Hayashi, M., Young, E. T., Kasahara, M. \& Cuasnicú, P. S. (2001) Evidence that human epididymal protein ARP plays a role in gamete fusion through complementary sites on the surface of the human egg. Biol Reprod, 65, 10001005.

Datti, A., Beccari, T., Emiliani, C., Stirling, J. L. \& Orlacchio, A. (1993) Blood testoterone levels are correlated with $\mathrm{b}-\mathrm{N}$-actylhexosaminidase activity in human caput epididymis. Biochem Mol Biol Int, 30, 1013-1020.

Diekman, A. B., Norton, E. J., Westbrook, V. A., Klotz, K. L., Naaby-Hansen, S. \& Herr, J. C. (2000) Anti-sperm antibodies from infertile patients and their cognate sperm antigens: a review. Identity between SAGA-1, the H6-3C4 antigen, and CD52. Am J Reprod Immunol, 43, 134-43.

Diekman, A. B., Westvrook-Cae, V. A., Naaby- Hansen, S., Klotz, K. L., Flickinger, C. J. \& Herr, J. C. (1997) Biochemical characterisation of sperm agglutination antigen-1, a human sperm surface antigen implicated in gamete interactions. Biol Reprod, 57, 1136-1144.

Elisen, M. G., van Kooij, R. J., Nolte, M. A., Marquart, J. A., Lock, T. M., Bouma, B. N. \& Meijers, J. C. (1998) Protein C inhibitor may modulate human sperm-oocyte interactions. Biol Reprod, 58, 670-7.

Fenichel, P., Cervoni, F., Hofman, P., Deckert, M., Emiliozzi, C., Hsi, B. L. \& Rossi, B. (1994) Expression of the complement regulatory protein CD59 on human spermatozoa: characterization and role in gametic interaction. Mol Reprod Develop, 38, 338-346.

Focarelli, R., Francavilla, S., Francavilla, F., Giovampaola, D. C., Santucci, A. \& Rosati, F. (1999) gp20, a sialylglycoprotein of the human capacitated sperm surface is the homologue of the leukocyte CD52 antigen: analysis of the effect of anti-CD52 monoclonal antibody (CAMPATH-1) on capacitated sperm. Mol Human Reprod, 5, 46-51.

Focarelli, R., Giovampaola, C. D., Seraglia, R., Brettoni, C., Sabatini, L., Pescaglini, M. \& Rosati, F. (1999) Biochemical and MALDI analysis of the human sperm antigen gp20, homologue of leukocyte CD52. Biochem Biophys Res Commun, 258, 639-643.

Focarelli, R., Giuffrida, A., Capparelli, S., Scibona, M., Menchinis-Fabris, F., Francavilla, F., Francavilla, S., Della Giovampaola, C. \& Rosati, F. (1998) Specific localization in the equatorial segment of $\mathrm{gp} 20$, a $20 \mathrm{kDa}$ sialylglycoprotein of the capcacitated human spermatozoon acquired during epididymal transit which is necessary to penetrate zona-free hamster eggs. Mol Human Reprod, 4, 119-125.

Hale, G., Rye, P. D., Warford, A., Lauder, I. \& Brito-Babapulle, A. (1993) The glycosylphosphatidylinositol-anchored lymphocyte antigen CDw52 is associated with the epididymal maturation of human spermatozoa. J Reprod Immunol, 23, 189-205.

Hammani-Hamza, S., Doussau, M., Bernard, J., Rogier, E., Duquenne, C., Richard, Y., Lefèvre, A., Finaz, C. M. \& Bernard, J. (2001) Cloning and sequencing of SOB3, a human gene coding for a sperm protein homologous to an antimicrobial protein and potentially involved in zona pellucida bin- ding. Mol Human Reprod, 7, 625-632.

Hayashi, M., Fujimoto, S., Takano, H., Ushika, T., Abe, K., Ishikura, H., Yoshida, M. C., Kirchhoff, C., Ishibashi, T. \& Kasahara, M. (1996) Characterization of a human glycoprotein with a potential role in sperm-egg fusion: cDNA cloning, immunohistochemical localization, and chromosomal assignment of the gene AEGL1). Genomics, 32, 367-374.

Hutter, H., Hammer, A., Blaschitz, A., Hartmann, M., Mahnert, W., Sedlmayr, P., Primus, G., Rosenkranz, C., Gebru, G., Henkel, R. \& Dohr, G. (1996) The monoclonal antibody GZS-1 detects a maturation-associated antigen of human spermatozoa that is also present on the surface of human mononuclear blood cells. J Reprod Immunol, 30, 115-32.

Isojima, S., Tsuji, Y., Kameda, K., Shigeta, M., Hakamori, S.-I. (1990): Coating antigens of human seminal plasma involved in fertilization. In: Gamete Interactions: Prospects for Immunocontraception, Alexander, N. J., Griffin, D., Spieler, J. M. D., Waites, G. M. H. (eds.), New York: Wiley-Liss, pp 155-174.

*Jury, J. A. \& Frayne, J. H. L. (1998) Sequence analysis of a variety of primate fertilin a genes: evidence for non-functional genes in the gorilla and man. Mol Reprod Develop, 51, 92-97.

*Jury, J. A., Frayne, J. \& Hall, L. (1997) The human fertilin a gene is nonfunctional: implications for its proposed role in fertililization. Biochem J, 321, 577-581.

Kameda, K., Takada, Y., Hasegawa, A., Tsuji, Y., Koyama, K. \& Isojima, S. (1991) Sperm immobilizing and fertilization-blocking monoclonal antibody $2 \mathrm{C} 6$ to human seminal plasma and characterization of the antigen epitope corresponding to the monoclonal antibody. J Reprod Immunol, 20, $27-41$.

Kameda, K., Tsuji, Y., Koyoma, K. \& Isojima, S. (1992) Comparative studies of the antigens recognised by sperm-immobilising monoclonal antibodies. Biol Reprod, 46, 349-357.

Kirchhoff, C., Habben, I., Ivell, R \& Krull, N. (1991) A major human epididymis-specific cDNA encodes a protein with sequence homology to extracellular proteinase inhibitors. Biol Reprod, 45, 350-357.

Kirchhoff, C., Krull, N., Pera, I. \& Ivell, R. (1993) A major mRNA of the human epididymis principal cells, HE5, encodes the leucocyte differentiation CDw52 antigen peptide backbone. Mol Reprod Develop, 34, :8-15.

Kirchhoff, C., Osterhoff, C. \& Young, L. (1996) Molecular cloning and characterization of HE1, a major secretory protein of the human epididymis. Biol Reprod, 54, :847-856.

Kirchhoff, C. (1994) A major messenger ribonucleic acid of the rodent epididymis encodes a small glycosylphosphatidylinositol-anchored lymphocyte surface antigen. Biol Reprod, 50, 896-902.

Kirchhoff, C. (1996) CD52 is the 'major maturation-associated' sperm membrane antigen. Mol Human Reprod, 2, 9-17.

Kirchhoff, C. (1998) Molecular characterization of epididymal proteins. Reviews of Reproduction, 3, 86-95.

Kirchhoff, C., Pera, L., Rust, W. \& Ivell, R. (1994) Major human epididymisspecific gene product, HE3, is the first representative of a novel gene family. Mol Reprod Develop, 37, 130-137.

Krätzschmar, J., Haendler, B., Eberspaecher, U., Roosterman, D., Donner, P. \& Schleuning, W.-D. (1996) The human cysteine-rich secretory protein (CRISP) family. Primary structure and tiissue distribution of CRISP-1, CRISP-2 and CRISP-3. Eur J Biochem, 236, 827-836.

Krull, N., Ivell, R., Osterhoff, C. \& Kirchhoff, C. (1993) Region-specific variation of gene expression in the human epididymis as revealed by in situ hybridization with tissue-specific cDNAs. Mol Reprod Develop, 34, 16-24.

Larsen, L. B., Rovn, P., Boisen, A., Berglund, L. \& Petersen, T. E. (1997) Primary structure of EPV20, a secretory glycoprotein continaing a previously uncharacteriszed type of domain. Eur J Biochem, 243, 437-441.

Laurell, M., Christensson, A., Abrahamson, P.-A., Stenflo, J. \& Lilja, H. (1992) Protein C inhibitor in human body fluids. Seminal plasma is rich in inhibitor antigen deriving from cells throughout the male reproductive system. J Clin Invest, 89, 1094-1101.

Lefèvre, A., Duquenne, C., Rousseau-Merck, M. F., Rogier, E. \& Finaz, C. (1999) Cloning and characterization of SOB1, a new testis-specific cDNA encoding a human sperm protein probably involved in oocyte recognition. Biochem Biophys Res Commun, 259, 60-6.

Lefèvre, A., Ruis, C. M., Chokomian, S., Duquenne, C. \& Finaz, C. (1997) Characterization and isolation of SOB2, a human sperm protein with a potential role in oocyte membrane binding. Mol Human Reprod, 3, 507-516.

Legare, C., Gaudreault, C., St-Jacques, S. \& Sullivan, R. (1999) P34H sperm 
protein is preferentially expressed by the human corpus epididymidis. Endocrinology, 140, 3318-3327.

Lin, Y. C., Sun, G. H., Lee. Y. M., Guo, Y. W. \& Liu, H. W. (2001) Cloning and Characterization of a Complementary DNA Encoding a Human Epididymis-Associated Disintegrin and Metalloprotease 7 Protein. Biol Reprod, 65, 944-950.

*Lin, Y., Kimmel, L. H., Myles, D. G. \& Primakoff, P. (1993) Molecular cloning of the human and monkey sperm surface protein PH-20. Proc Nat Acad Sci US, 90, 10071-10075.

Liu, H. W., Liu, Y. C., Chao, C. F., Chang, S. Y. \& Sun, G. H. (2000) GP-83 and GP-39, two glycoproteins secreted by human epididymis and conjugated to spermatozoa during maturation. Mol Human Reprod, 6, 422-428.

Liu, Q., Hamil, K. G., Sivashanmugam, P., Grossman, G., Soundararajan, R., Rao, A. J., Richardson, R. T., Zhang, Y. L., O'Rand, M. G., Petrusz, P., French, F. S. \& Hall, S. H. (2001) Primate epididymis-specific proteins: characterization of ESC42, a novel protein containing a trefoil-like motif in monkey and human. Endocrinology, 142, 4529-39.

Mahony, M. C. \& Alexander, N. J. (1991) Sites of antisperm antibody action. Hum Reprod, 6, 1426-30.

Malm, J., Sorensen, O., Persson, T., Frohm-Nilsson, M., Johansson, B., Bjartell, A., Lilja, H., Stahle-Backdahl, M., Borregaard, N. \& Egesten, A. (2000) The human cationic antimicrobial protein (hCAP-18) is expressed in the epithelium of human epididymis, is present in seminal plasma at high concentrations, and is attached to spermatozoa. Infect Immun, 68, 4297-302. Miranda, P. V. \& Tezon, J. G. (1992) Characterization of fibronectin as a marker for human epididymal sperm maturation. Mol Reprod Develop, 33, 443450 .

Martinez-Ruiz, C. M., Duquenne, C., Treton, D., Lefèvre, A. \& Finaz, C. (1998) SOB3, a human sperm protein involved in zona pellucida binding: physiological and biochemical analysis, purification. Mol Reprod Develop, 49, 286-297.

Moore, A., Penfold, L. M., Johnson, J. L. \& Latchman, D. S. (1993) Human sperm-egg binding is inhibited by peptides corresponding to core region of an acrosomal serine protease inhibitor. Mol Reprod Develop, 34, 280-291.

Naz, R. Q., Morte, C., Garcia-Framus, V., Kaplan, P. \& Martinez, P. (1993) Characterization of a sperm-specific monoclonal antibody and isolatio of 95 kilodalton fertilization antigen-2 from human sperm. Biol Reprod, 49, 12361244.

O'Bryan, M. K., Mallidas, C., Murphy, B. F. \& Baker, H. W. G. (1994) Immunohistological localization of clusterin in the male genital tract in humans and marmosets. Biol Reprod, 50, 502-509.

O'Bryan, M. K., Murphy, B. F., Liu, D. Y., Clarke, G. N. \& Baker, H. W. G. (1994) The use of anticlusterin monoclonal antibodies for the combined assessment of human sperm morphology and acrosome integrity. Human Reprod, 9, 1490-1496.

Osterhoff, C., Ivell, R. \& Kirchhoff, C. (1997) Cloning of a human epididymis-specific mRNA, HE6, encoding a novel member of the seven transmembrane-domain receptor superfamily. DNA and Cell Biol, 16, 379-389.

Osterhoff, C., Kirchhoff, C.. Krull, N. \& Ivell, R. (1994) Molecular cloning and characteriztation of a novel human sperm antigen (HE2) specifically expressed in the proximal epididymis. Biol Reprod, 50, 516-525.

Osterhoff, C., Lassalle, B., Finaz, C., Ivell, R. \& Kirchhoff, C. (1993) A secretory protein of the human epididymis appears to be involved in the gamete recognition process. J Reprod Fertil, Abstract Series 12, C31, 21.

Paju, A., Bjartell, A., Zhang, W. M., Nordling, S., Borgstrom, A., Hansson, J., \& Stenman, U. H. (2000) Expression and characterization of trypsinogen produced in the human male genital tract. Am J Pathol. 157, 2011-21.

Patrizio, P. \& Salameh, W. A. (1998) Expression of the cystic fibrosis transmembrane conductance regulator (CFTR) mRNA in normal and pathological adult human epididymis. J Reprod Fertil, Supplement 53, 261-270.

Raczek, S., Yeung, C. H., Hasilik, A., Robenek, R., Hertle, L., Schulze, H \& Cooper, T. G. (1995) Immunocytochemical localisation of some lysosomal hydrolases, their presence in luminal fluid and their directional secretion by human epididymal cells in culture. Cell Tiss Res, 280, 415-426.

Richardson, R. T., Sivashanmugam, P., Hall, S. H., Hamil, K. G., Moore, P. A., Ruben, S. M., French, F. S. \& O'Rand, M.(2001) Cloning and sequencing of human Eppin: a novel family of protease inhibitors expressed in the epididymis and testis. Gene. 270, 93-102.

Ross, P., Vigneault, N., Provencher, S., Potier, M. \& Roberts, K. D. (1993) Partial characterization of galactosyltransferase in human seminal plasma and its distribution in the human epididymis. J Reprod Fertil, 98, 129-137.

Saalmann A, Munz S, Ellerbcrock K, Ivell R, Kirchhoff C. Novel sperm-binding proteins of epididymal origin contain four fibronectin type-II modules. Mol Reprod Develop, 2001;58:88-100.

Sanjurjo, C., Dawidowsky, A. R., Cameo, M. S., Gonzalez Echeverria, F. \& Blaquier, J. A. (1990) Participation of human epididymal sperm coating antigens in fertilization. J Androl, 11, 476-483.

Schaller, J., Glander, H. J. \& Dethloff, J. (1993) Evidence of B1 integrins and fibronectin on spermatogenic cells in human testis. Human Reprod, 8, 1873 1878.

Simpson, K. L. \& Holmes, C. H. (1994) Presence of the complement-regulatory protein membrane cofactor protein (MCP, CD46) as a membrane-associated product in seminal plasma. J Reprod Fertil, 102, 419-424.

Sun, G. H., Ln, Y. C., Guo, Y. W., Chang, S. \& Liu, H. W. (2000a) Purification of GP-83, a glycoprotein secreted by the human epididymis and conjugated tio mature spermatozoa. Mol Human Reprod, 6, 429-444.

Sun, G. H., Liu, H. W., Lin, Y. C., Yu, D. S. \& Chang, S. Y. (2000b) Identification of maturation-related wheat-germ lectin-binding proteins in the culture of human corpus epididymal epithelial cells. Arch Androl, 45, 53-60. Tesarik, J., Drahorad, J. \& Peknicova, J. (1988) Subcellular immunochemical localization of acrosin in human spermatozoa during the acrosome reaction and zona pellucida penetration. Fertil Steril, 50, 133-141.

Tezon, J. G., Ramella, E., Cameo, M. S., Vazquez, M. H. \& Blaquier, J. A. (1985) Immunocytochemical localization of secretion antigens in the human epididymis and their association with spermatozoa. Biol Reprod, 32, 591-597. Tokugawa, Y., Kunishige, I., Kubota, Y., Shimoya, K., Nobunaga, T., Kimura, T., Saji, F., Murata, Y., Eguchi, N., Oda, H., Urade, Y. \& Hayaishi, O. (1998) Lipocalin-type prostaglandin $S$ synthase in human male reproduticve organs and seminal plasma. Biol Reprod, 58, 600-607.

Wong, P. Y. D., Huang, S. J., Leung, A. Y. H., Fu, W. O., Chung, Y. W., Zhou, T. S., Yip, W. W. K. \& Chan, W. K. L. (1992) Physiology and pathophysiology of electrolyte transport in the epididymis. In: Spermatogenesis, Fertilization, Contraception. Molecular, Cellular and Endocrine Events in Male Reproduction. Nieschlag, E., Habenicht, U.-F. (eds), Schering Foundation Symposium, Springer-Verlag, Berlin. Pp. 319-344.

Yan, Y. C., Mitsudo, S. M., Wang, L. F. \& Koide, S. S. (1984) Immunolocalization of a sperm membrane protein in human male reproductive organs. Fertil Steril, 42, 614-617.

Yeung, C. H., Cooper, T. G. \& Senge, T. (1990) Histochemical localization and quantification of a-glucosidase in the epididymis of men and laboratory animals. Biol Reprod, 42, 669-676.

Yeung, C.-H., Schröter, S., Wagenfeld, A., Kirchhoff, C., Kliesch, S., Poser, D., Weinbauer, G. F., Nieschlag, E. \& Cooper, T. G. (1997) Interaction of the human epididymal protein CD52 (HE5) with epididymal spermatozoa from men and cynomolgus monkeys. Mol Reprod Develop, 48, 267-275.

Zhu, X. \& Naz, R. K. (1997) Fertilization antigen-1: cDNA cloning, testisspecific expression, and immunocontraceptive effects. Proc Nat Acad Sci US, $29,4704-4709$. 
sion of dyes that bind to nucleoproteins (aniline blue binds to the remaining histones) or desoxyribonucleic acid itself (acridine orange fluoresces red with single stranded and green with double stranded DNA). With both methods a decrease in the accessibility of the dye is interpreted as an increase in the extent of chromatin condensation (Fig. 1h).

Chromatin condensation reflects oxidation of sulphydryl groups of protamines [3] but nothing is known of any human enzymes involved.

\section{Fertilising ability in vivo and in vitro}

Ethical standards dictate that the only studies on the fertilising capacity of sperm obtained from the human epididymis are made on infertile men. In these studies epididymovasostomy is performed on azoospermic men with epididymal occlusion. The site of anastomosis of the vas to the epididymis occurs above the site of occlusion so that different extents of the epididymis are bypassed. It is observed that the more of the epididymis the sperm have passed through before entering the vas deferens, the higher the pregnancy rate (Fig. 1i). Assisted reproduction techniques have permitted pregnancies to be initiated by IVF of sperm removed from different regions of an occluded epididymis. It has demonstrated that both fertilisation and pregnancy rates are higher, the longer the length of epididymis the spermatozoa have encountered (Fig. 1j).

The longer the epididymal passage, the greater the chance of interaction with epididymal secretions.

\section{EPIDIDYMAL PROTEINS INVOLVED IN SPERM MATURATION}

Several techniques have been applied to the study of epididymal proteins that may be involved in the maturation and storage of spermatozoa. The earlier work on proteins involved the raising of polyclonal or monoclonal antibodies against human ejaculated spermatozoa $[2,4]$, because coating proteins should be adherent to them; against proteins eluted from the ejaculated sperm surface [48], because eluted sperm proteins can promote zona binding [29]; and against human seminal fluid proteins (e.g. [31]), because secreted epididymal sperm-coating proteins are found in seminal plasma. Antibodies against known proteins from other human organs suspected of being involved (e.g. fibronectin or clusterin) have been employed, and the activity of enzymes measured in homogenates [43] or by enzyme histochemistry [49].

More recently, molecular biology techniques such as cloning from gene-specific probes and differential library screening have been applied to the epididymis (see [33]) and revealed transcripts of genes that are expressed solely in the epididymis. Oligonucleotide sequence data and the consensus amino acid composition of these proteins have revealed surprising identities between proteins with different functions. The nucleotide sequence of one epididymal secretion involved in sperm-zona binding (P34H) identifies it as a member of the short-chain dehydrogenase/reductase family of proteins and it has carbonyl reductase activity. Another epididymal protein involved in sperm-zona binding (SOB3: [24]) has the identical sequence as a human epididymal cationic anti-microbial protein (hCAP-18: [37]).

(Some confusion in this field is sown by the publication by Agerberth et al [1] who identified the hCAP-18 gene in the human testis. In fact, the authors used commercial filters that are preloaded with mRNA from various human organs. It is known (from the presence of a purely epididymal secretion HE5 in the 'testis' field of such arrays [C. Kirchhoff, personal communication]) that such samples often contain mRNA from 'total scrotal contents' and thus contain epididymal tissue in addition. In the case of hCAP18/SOB3, antibodies do not detect the protein in the testis, making it a true epididymal secretion.)

One major maturation antigen of the human epididymis (CD52) has been discovered by several groups and called variously H6-3C4 antigen [32], HE5 [34], GZS-1 [28], SAGA-1 [11], S19 antigen [36] and gp20 [17, 18] (see [12]).

Table 1 lists the proteins identified to date as secretions of the human epididymis that may be involved in the acquisition of fertilising capacity of epididymal spermatozoa. Their names, pseudonyms, molecular weight, pI, proven functions and suspected role in fertilisation are given. Where given, the site of expression of the gene and protein in the organ are presented, as well as the extent of expression, and the location in the epididymis where sperm are first coated by the secretion and the site of the sperm where the antigen is located.

\section{Solely testicular proteins}

Testicular proteins involved in sperm-egg contact are also listed for completeness. They are inherent components of sperm before they leave the testis and are thought to function in zona binding and fusion with the oocyte.

\section{Testicular and epididymal proteins}

Other proteins are expressed in both the testis and epididymis. The epididymal regions listed are those described in the papers cited, although as the human caput contains both a common epididymal duct and many efferent ducts [50] the term 'caput' will include efferent ducts. Of those solely in the caput region, clusterin binds to lipids that are exposed on dead spermatozoa. Of efferent duct proteins also secreted more distally in the corpus epididymidis, one is a protease inhibitor (Eppin) and three (SOB1, ARP and fibronectin) are involved in fusion with the vitellus. A role in 
egg fusion is deduced from the reduced number of sperm penetrating zona-free hamster oocytes after treatment of sperm with antibodies to the protein and showing that zona binding, motility and the acrosome reaction are not affected by the antibody. Steric hindrance by the antibody to an adjacent sperm site truly involved in binding is a concern and sometimes the smaller Fab Ig fragments are used. A location on the equatorial region of the acrosome (the site of sperm-egg contact) is usually consistent with a function in sperm-egg fusion. This is not always the case, however, and one sperm coating protein eluted by high ionic strength is located over the acrosomal region [48] and yet its antibody prevents sperm-egg fusion not sperm-zona binding [44]. This may be because the protein relocates to the equatorial segment during capacitation, which is the case for gp20/CD52 [16].

The location in the epididymis of several proteins also present in the testis (PDGS, a lipocalin) is not accurately given. In most cases it can be assumed, and in others it is clear from histological sections, that the corpus epididymidis was examined, however this does not necessarily imply that the protein is absent from other areas, since they may not have been examined or it may not be present (as in the case of BCAVD: [27]). Expression of serpin (involved in zona binding and vitellus fusion) and trypsinogen (a precursor for a proteolytic enzyme/zona binding protein) is found more distally in the cauda epididymidis as well.

\section{Solely epididymal proteins}

As for the proteins above, some are expressed solely the caput (or efferent ducts) and throughout the duct. HE6 (a suspected epithelial transporter) is solely located in the caput but the reports of a caput expression of proteins $\mathrm{C}$ and $\mathrm{S}$, proteases involved in immune suppression, may reflect the fact that only tissue from CAVB patients was examined where no more distal tissue is present, so these proteins may be present in more distal regions of normal epididymides.

Proteins involved in zona binding (3B2F antigen) and vitellus fusion (SOB2) are found throughout the epididymis but a regional gradation of expression/activity of other epididymal proteins is evident. The activities of the enzymes NAG $\beta$-glucosidase and $\beta$-galactosidase are higher in the ED than the more distal regions of epididymis and vas deferens. The expression of HE2 (vitellus fusion/antimicrobial activity) and galactosyl transferase activity are also greater in the caput region.

On the other hand, $\alpha$-fucosidase, $\alpha$-mannosidase and $\beta$-glucuronidase are more active in the epididymis than efferent ducts or vas. The corpus epididymidis similarly displays higher expression than the caput or cauda of P34H (zona binding). For HE1 (a sterol binding protein) and the novel HE3, a biphasic expression is present with expression higher in the vas deferens than the cauda. For products that are liberated into the lumen, the significance of localised expression in the corpus is not clear, since the product would move with the spermatozoa distally and mix with them there. Indeed, for secretions P34H [5] and HE5/CD52 [53] there are higher amounts of protein on sperm from the cauda than corpus despite the lower gene expression in the cauda.

Nevertheless, proteins expressed along the entire duct but in higher amounts in the more distal regions would provide more secretion per sperm than others and may be involved in storage of sperm in the cauda. A sperm coating protein involved in egg fusion, the enzyme $\alpha$-glucosidase and the antimicrobial hCAP-18 all provide such distal gradients of secretion. Other proteins are found solely in the corpus and cauda (the protease GP-83, GP-39 [vitellus fusion]) or cauda alone (HE4, HE12), the latter thought to be decapacitation factors that keep sperm quiescent until ejaculation.

\section{Interaction of proteins with spermatozoa}

Epididymal proteins held electrostatically to the sperm surface can be eluted with high ionic strength medium and include sperm coating protein [44] and ARP [35]. The former was implicated in sperm-egg fusion because antibodies to it blocked penetration of human sperm into zona-free hamster eggs. By contrast, ARP was easily eluted from the sperm surface and was not considered to function in spermegg fusion in the way that the rodent equivalent (Protein $\mathrm{D} / \mathrm{E}$ [AEG]) does in the rat [42]. Recent studies, however, have indicated that some ARP remains on the sperm equatorial region after high salt extraction and that antibodies against ARP block sperm-egg penetration [6]. By analogy with the rat epididymis (about which most is known in this regard) it is possible that the ionic strength within the human epididymal canal is low, because of high concentrations of uncharged organic solutes, and this would keep these proteins on the sperm [8].

At least two epididymal secretions (CD52 and P34H) are to held by glycerophoshoinositol anchors to the sperm membrane. These anchor the protein to the membrane of the epididymal cell that sheds vesicular 'epididymosomes' into the lumen. In both cases transfer to sperm is mediated by such vesicles $[21,53]$. $\mathrm{P} 34 \mathrm{H}$ protein remains on the sperm head until the acrosome reaction, when its role in zona binding is complete [5].

\section{SUMMARY}

In addition to proteins on sperm as they enter the duct, additional proteins are added, sometimes the same as testicular proteins (in the case of clusterin different isoforms) but more often different, epididymal specific secretions. As sperm move through the human epididymis they encounter a varied and varying environment with respect to the pro- 
teins with which they come into contact. In the proximal epididymis sperm are subjected to the action of certain enzymes and exposure to proteins involved in membrane modification and sperm-egg fusion. In the middle region another set of enzymes become active and proteins predominate, associated with sterol transport (HE1) that could modify the membrane in such as way as to permit the uptake of GPI-anchored zona binding protein P34H. More distally sperm encounter increasing gradients of glucosidase and protease, proteins involved in both zona binding and oocyte fusion, the major maturation antigen CD52, antimicrobial activity and decapacitation factors, that help them to survive before ejaculation. Despite the difficulties in assessing the precise epididymal regions from which mRNA and proteins have been detected and discrepancies between reports of the same proteins, Figure 2 attempts to provide a broad picture of regional variations in the location of proteins in the epithelium. Sperm will come into contact with these secretions at these sites and more distally.

Adherence of the proteins to different domains (plasma membrane over the acrosome or equatorial acrosomal segment) may depend on the nature of the protein, the lipid composition of the particular membrane and the ionic and environment in which the sperm finds itself. The eventual location on a capacitated sperm (acrosomal membrane) or acrosome-reacted sperm (equatorial region) may dictate their role in, for example, zona-binding $(\mathrm{P} 34 \mathrm{H})$ or oocytebinding (gp20) (Fig. 3). Both the proteins and the sperm membranes may be modified during epididymal transit by the range of enzyme activities to which sperm are subjected in different epididymal regions (e.g. glycosyltransferases, glycosidases and proteases) and which may add to or remove carbohydrates and peptides from the sperm surface. The activity of proteases are in turn being modified by protease inhibitors liberated from the epithelium and attached to spermatozoa.

\section{Acknowledgments}

Our work cited in this report was largely funded by the Deutsche Forschungsgemeinnschaft.

\section{PROXIMAL}

\section{Clusterin}

\section{SOB1}

\section{Eppin} HE2
MIDDLE

DISTAL

\section{FN}

\section{P34H}

\section{HE1}

\section{HE3}




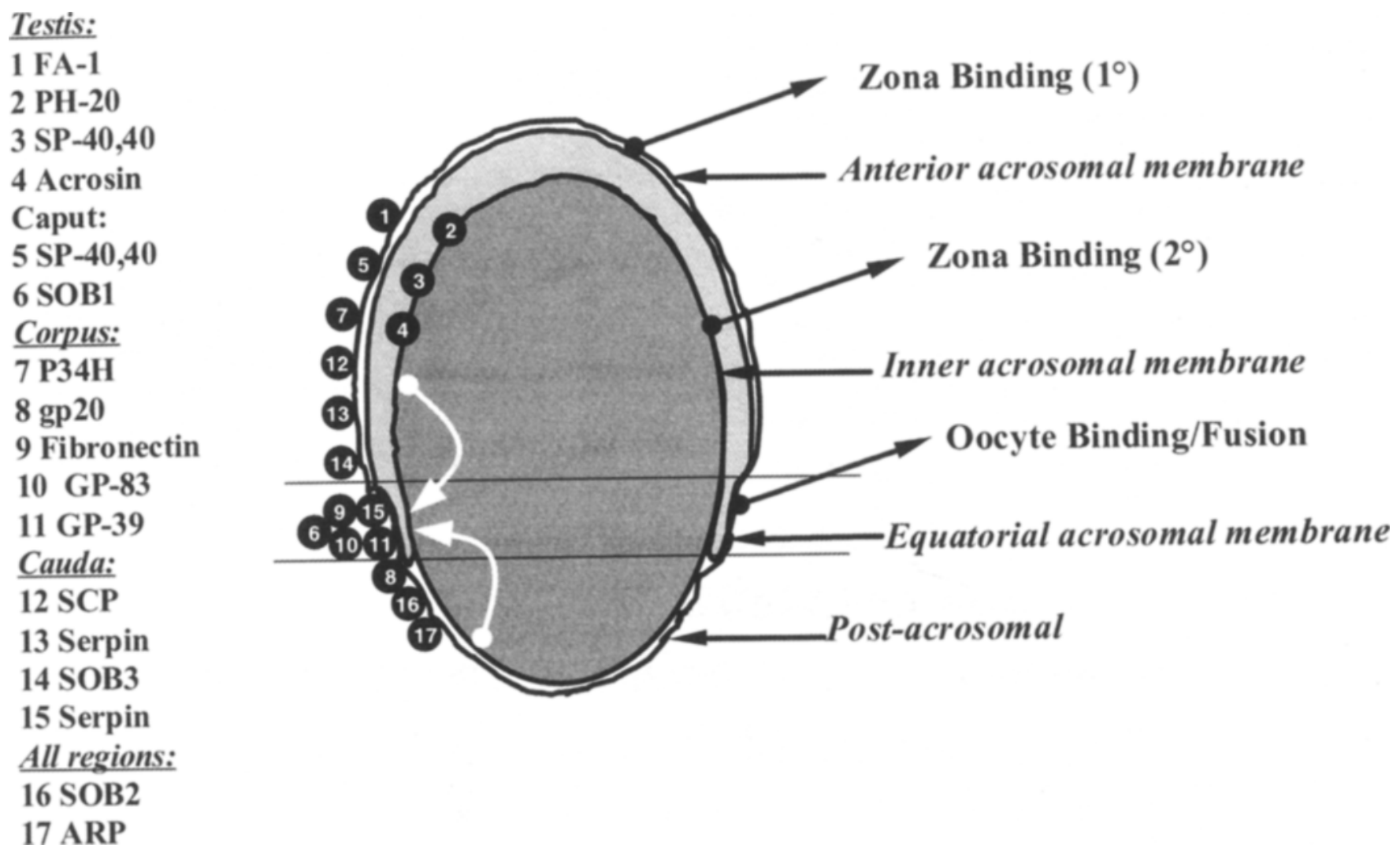

Figure 3 : Schematic representation (not to scale) of the location of intrinsic (testicular) and extrinsic (secreted, epididymal) proteins on different membranes of the human sperm head with proposed functions in fertilisation.

\section{REFERENCES}

1. AGERBERTH B., GUNNE H., ODEBERG J., KOGNER P., BOMAN H.G., GUDMUNDSSON G.H. : FALL-39, a putative human peptide antibiotic, is cysteine-free and expressed in bone marrow and testis. Proc. Nat. Acad. Sci. US., 1995, 92 : 195-199.

2. BATOVA I., KAMEDA K., HASEGAWA A., KOYAMA K., TSUJI Y., ISOJIMA S. : Monoclonal antibody recognising an apparent peptide epitope of human seminal plasma glycoprotein and exhibiting sperm immobilizing activity. J. Reprod. Immunol., 1990, $17: 1-6$.

3. BEDFORD J.M., CALVIN H., COOPER G.W. : The maturation of spermatozoa in the human epididymis. J. Reprod. Fertil., 1973, Suppl $18:$ 199-213.

4. BOUÉ F., LASSALLE B., DUQUENNE C.et al. : Human sperm proteins from testicular and epididymal origin that participate is fertilization: modulation of sperm binding to zona-free hamster oocytes, using monocional antibodies. Mol. Reprod. Develop., $1992,33: 470-480$.

5 . BOUÉ F., BERUBÉ B., DE LAMIRANDE E., GAGNON C., SULLIVAN R. : Human sperm-zona pellucida interaction in inhibited by an antiserum against a hamster sperm protein. Biol. Reprod., 1994, 51 : 577-587.

6. COHEN D.J., ELLERMAN D.A., BUSSO D. et al. : Evidence that human epididymal protein ARP plays a role in gamete fusion through complementary sites on the surface of the human egg. Biol. Reprod., 2001, 65 : 1000-1005.

7. COOPER T.G. : Apologie de la fonction de l'épididyme dans l'espèce humaine. Contracept. Fertil. Sex., 1992, 20 : 363-373.

8. COOPER T.G. : Interactions between epididymal secretions and spermatozoa.. J. Reprod. Fertil., 1998, Suppl 53 : 119-136.

9. COOPER T.G., RACZEK S., YEUNG C.H., SCHWAB E., SCHULZE H., HERTLE L. : Composition of fluids obtained from human epididymal cysts. Urol. Res, 1992, 20 : 275-280.

10. DELPECH S., LECOMTE P., LECOMTE C. : Étude in vitro chez l'homme de la liason des spermatozoïdes épididymaires à la zone pellucide. J. Gynecol. Obstet. Biol. Reprod., 1988, 17 : 339-342.

11. DIEKMAN A.B., WESTBROOK-CASE V.A., NAABYHANSEN S., KLOTZ K.L., FLICKINGER C.J., HERR J.C. : Biochemical characterization of sperm agglutination antigen-1, a human sperm surface antigen implicated in gamete interactions. Biol. Reprod., 1997, 57 : 1136-1144.

12. DIEKMAN A.B., NORTON E.J., WESTBROOK V.A., KLOTZ K.L., NAABY-HANSEN S., HERR J.C. : Anti-sperm antibodies from infertile patients and their cognate sperm antigens: a review. Identity between SAGA-1, the H6-3C4 antigen, and CD52. Am. J. Reprod. Immunol., 2000, 43 : 134-43.

13. EDIRISINGHER W.R., JUNK S.M., MATSON P.L., YOVICH J.L. : Changes in motility patterns by in-vitro culture of fresh and frozen/thawed testicular and epididymal spermatozoa: implication for planning treatment by intracytoplasmic sperm injection. Human Reprod., 1996, $11:$ 2474-2476.

14. FINAZ C., LEFEVRE A. : Gamete recognition in mammals: sperm and zona pellucida interactions. Contracept. Fertil. Sex., $1998,26,542-548$. 
15. FINAZ C., MARTIN-RUIZ C., LEFÈVRE A. : Interaction des gamètes et protéines de reconnaissance. Médicine/Sciences, 1998, 14 : 175-182.

16. FOCARELLI R., GIUFFRIDA A., CAPPARELLI S. et al. : Specific localization in the equatorial segment of gp20, a $20 \mathrm{kDa}$ sialylglycoprotein of the capacitated human spermatozoon acquired during epididymal transit which is necessary to penetrate zona-free hamster eggs. Mol. Human Reprod., 1998, 4 : 119-125.

17. FOCARELLI R., FRANCAVILLA S., FRANCAVILLA F., GIOVAMPAOLA D.C., SANTUCCI A., ROSATI F. : gp20, a sialylglycoprotein of the human capacitated sperm surface is the homologue of the leukocyte CD52 antigen: analysis of the effect of anti-CD52 monoclonal antibody (CAMPATH-1) on capacitated sperm. Mol. Human Reprod., 1999, 5 : 46-51.

18. FOCARELLI R., GIOVAMPAOLA C.D., SERAGLIA R. et al. : Biochemical and MALDI analysis of the human sperm antigen gp20, homologue of leukocyte CD52. Biochem. Biophys. Res. Commun, 1999, $258:$ 639-643.

19. FOGDESTAM I., FALL M., NILSSON S. : Microsurgical epididymovasostomy in the treatment of occlusive azoospermia. Fertil. Steril., 1986, 46 : 925-929.

20. FOURNIER-DELPECH A., GUÉRIN Y. : Interactions des spermatozoïdes avec le zone pellucide. Contracept. Fertil. Steril., $1991,19: 825-832$.

21. FRENETTE G., SULLIVAN R. : Prostasome-like particles are involved in the transfer of $\mathrm{P} 25 \mathrm{~g}$ from the bovine epididymal fluid to the sperm surface. Mol. Reprod. Develop., 2001, 59 : 115-121.

22. GAGO C., SOLER C., PEREZ-SANCHEZ F., YEUNG C.H., COOPER T.G. : Effect of cetrorelix on sperm morphology during migration through the epididymis in the cynomolgus macaque (Macaca fascicularis). Am. J. Primatol., 2000, 51 : 10317.

23. GOLAN R., COOPER T.G, OSCHRY Y.et al. : Changes in chromatin condensation of human spermatozoa during epididymal transit as determined by flow cytometry. Human Reprod., 1996, $11: 1457-1462$.

24. HAMMANI-HAMZA S., DOUSSAU M., BERNARD J. et al. : Cloning and sequencing of SOB3, a human gene coding for a sperm protein homologous to an antimicrobial protein and potentially involved in zona pellucida binding. Mol. Human Reprod., 2001, $7: 625-632$.

25. HAIDL G., BADURA B., HINSCH K.D., GHYCZY M., GAREI B.J., SCHILL W.B. : Disturbances of sperm flagella due to failure of epididymal maturation and their possible relationship to phospholipids. Human Reprod., 1993, 8 : 1070-1073.

26. HAIDL G; BADURA B., SCHILL W.B. : Function of human epididymal spermatozoa. J. Androl., 1994, 15 : 23S-27S.

27. HE X., SHEN L., BJARTELL A., MALM J., LILJA H, DAHLBÄCK, B. : The gene encoding vitamin K-dependent anticoagulant protein $\mathrm{C}$ is expressed in human male reproductive tissues. J. Histochem. Cytochem., 1995, 43 : 563-570.

28. HUTTER H., HAMMER A., BLASCHITZ A.et al. : The monoclonal antibody GZS-1 detects a maturation-associated antigen of human spermatozoa that is also present on the surface of human mononuclear blood cells. J. Reprod. Immunol., 1996, 30 : 115-32.

29. JEAN M., DACHEUX J.L., DACHEUX F., SAGOT P., LOPES
P., BARRIERE P. : Increased zona-binding ability after incubation of spermatozoa with proteins extracted from spermatozoa of fertile men. J. Reprod. Fertil.,1995, $105:$ 43-48.

30. JOW W.W., STECKEL J., SCHLEGEL P.N., MAGID M.S., GOLDSTEIN M. : Motile sperm in human testis biopsy specimens. J. Androl., 1993, 14 : 194-198.

31. KAMEDA.K., TAKADA Y., HASEGAWA A., TSUJI Y., KOYAMA K., ISOJIMA S. : Sperm immobilizing and fertilization-blocking monoclonal antibody $2 \mathrm{C} 6$ to human seminal plasma and characterization of the antigen epitope corresponding to the monoclonal antibody. J. Reprod. Immunol., 1991, $20: 27-41$.

32. KAMEDA K., TSUJI Y., KOYOMA K., ISOJIMA S. : Comparative studies of the antigens recognised by sperm-immobilising monoclonal antibodies. Biol. Reprod., 1992, 46 : 349-357.

33. KIRCHHOFF C. : Molecular characterization of epididymal proteins. Rev. Reprod., 1998, 3 : 86-95.

34. KIRCHHOFF C., KRULL N., PERA I., IVELL R. : A major mRNA of the human epididymis principal cells, HE5, encodes the leucocyte differentiation CDw52 antigen peptide backbone. Mol. Reprod. Develop., 1993, 34 : 8-15.

35. KRÄTZSCHMAR J., HAENDLER B., EBERSPAECHER U., ROOSTERMAN D., DONNER P., SCHLEUNING W.D. : The human cysteine-rich secretory protein (CRISP) family. Primary structure and tissue distribution of CRISP-1, CRISP-2 and CRISP-3. Europ J. Biochem., 1996, $236:$ 827-836.

36. MAHONY M.C., ALEXANDER N.J. : Sites of antisperm antibody action. Human Reprod., 1991, 6 : 1426-1430.

37. MALM J., SORENSEN O., PERSSON T. et al. : The human cationic antimicrobial protein (hCAP-18) is expressed in the epithelium of human epididymis, is present in seminal plasma at high concentrations, and is attached to spermatozoa. Infec.t Immun., 2000, $68:$ 4297-302.

38. MATHIEU C., GUÉRIN J.F., COGNAT M., LEJEUNE H., PINATEL M.C., LORNAGE J. : Motility and fertilizing capacity of epididymal human spermatozoa in normal and pathological cases. Fertil. Steril., 1992, $57: 871-876$.

39. MOORE H.D.M., CURRY M.R., PENFOLD L.M., PRYOR J.P. : The culture of human epididymal epithelium and in vitro maturation of epididymal spermatozoa. Fertil. Steril., 1992, 58 : 776-783.

40. MOORE, H.D.M., HARTMANN T.D., PRYOR J.P. : Development of the oocyte-penetrating capacity of spermatozoa in the human epididymis. Int. J. Androl., 1983, $6: 310-318$.

41. PATRIZIO P., ORD T., SILBER S.J., ASCH R.H. : Correlation between epididymal length and fertilization rate of men with congenital absence of the vas deferens. Fertil. Steril,, 1994, 61 : 265-268.

42. ROCHWERGER L., CUASNICÚ P.S. : Redistribution of a rat sperm epididymal glycoprotein after in vitro and in vivo capacitation. Mol. Reprod. Develop., 1992, 31 : 34-41.

43. ROSS P., VIGNEAULT N., PROVENCHER S., POTIER M., ROBERTS K.D. : Partial characterization of galactosyltransferase in human seminal plasma and its distribution in the human epididymis. J. Reprod. Fertil., 1993, 98 : 129-137.

44. SANJURJO C., DAWIDOWSKY A.R., CAMEO M.S., GONZALÉZ ECHEVERRÍA F., BLAQUIER J.A. : Participation of human epididymal sperm coating antigens in fertilization. J. Androl., 1990, $11:$ 476-483.

45. SCHIRREN C. : Gewebsentnahme aus dem Nebenhoden zu dia- 
gnostischen Zwecken? Andrologia, 1982, 14 : 461-462.

46. SCHMIDT S.S., SCHOYSMAN R., STEWART B.H. : Surgical approaches to male infertility. In: Hafez, E.S.E. eds. Human Semen and Fertility Regulation in Men., 1976: 476-493.

47. SOLER C., PÉREZ-SÁNCHEZ F., SCHULZE H., BERGMANN M., OBERPENNING F., YEUNG C., COOPER T.G. : Objective evaluation of the morphology of human epididymal sperm heads. Int. J. Androl., 2000, 23 : 77-84.

48. TEZÓN J.G., RAMELLA E., CAMEO M.S., VAZQUEZ M.H., BLAQUIER J.A. : Immunocytochemical localization of secretion antigens in the human epididymis and their association with spermatozoa. Biol. Reprod., 1985, $32: 591-597$.

49. YEUNG C.H., COOPER T.G., SENGE T. : Histochemical localization and quantification of $\alpha$-glucosidase in the epididymis of men and laboratory animals. Biol. Reprod., 1990, 42 : 669-676.

50. YEUNG C.H., COOPER T.G., BERGMANN M., SCHULZE H. : Organization of tubules in the human caput epididymidis and the ultrastructure of their epithelia. Am J. Anat., 1991,191 : 261-279.

51. YEUNG C.H., COOPER T.G., OBERPENNING F.; SCHULZE $\mathrm{H}$ :, NIESCHLAG E. : Changes in movement characteristics of human spermatozoa along the length of the epididymis. Biol. Reprod., 1993, 49 : 274-280.

52. YEUNG C.H., PEREZ-SANCHEZ F., SOLER C., POSER D., KLIESCH S., COOPER T.G. : Maturation of human spermatozoa (from selected epididymides of prostatic carcinoma patients) with respect to their morphology and ability to undergo the acrosome reaction. Hum. Reprod. Update, 1997, 3 : 205-13.

53. YEUNG C.H., SCHRÖTER S., WAGENFELD A. et al. : Interaction of the human epididymal protein CD52 (HE5) with epididymal spermatozoa from men and cynomolgus monkeys. Mol. Reprod. Develop., 1997, 48 : 267-275.

54. WIESE K., HAIDL G., OPPER C., SCHILL W.B. : Erhöhte Membranrigidität bei Spermatozoen mit mangelnder Nebenhodenausreifung. Fertilität, 1996, 12 : 91-94. 